\title{
Perinatal ischemic stroke: a five-year retrospective study in a level-III maternity
}

\author{
Acidente vascular cerebral isquêmico perinatal: \\ estudo retrospectivo de 5 anos em maternidade nível III
}

\author{
Virgínia Machado ${ }^{1}$, Sónia Pimentel ${ }^{1}$, Filomena Pinto ${ }^{1}, J_{\text {José Nona }}{ }^{1}$
}

\begin{abstract}
Objective: To study the incidence, clinical presentation, risk factors, imaging diagnosis, and clinical outcome of perinatal stroke. Methods: Data was retrospectively collected from full-term newborns admitted to the neonatal unit of a level III maternity in Lisbon with cerebral stroke, from January 2007 to December 2011. Results: There were 11 cases of stroke: nine were arterial ischemic stroke and two were cerebral venous sinus thrombosis. We estimated an incidence of arterial ischemic stroke of 1.6/5,000 births and of cerebral venous sinus thrombosis of 7.2/100,000 births. There were two cases of recurrent stroke. Eight patients presented with symptoms while the remaining three were asymptomatic and incidentally diagnosed. The most frequently registered symptoms $(8 / 11)$ were seizures; in that, generalized clonic (3/8) and focal clonic (5/8). Strokes were more commonly left-sided (9/11), and the most affected artery was the left middle cerebral artery (8/11). Transfontanelle ultrasound was positive in most of the patients (10/11), and stroke was confirmed by cerebral magnetic resonance in all patients. Electroencephalographic recordings were carried out in five patients and were abnormal in three (focal abnormalities $n=2$, burst-suppression pattern $n=1$ ). Eight patients had previously identified risk factors for neonatal stroke which included obstetric and neonatal causes. Ten patients were followed up at outpatients setting; four patients developed motor deficits and one presented with epilepsy. Conclusions: Although a modest and heterogeneous sample, this study emphasizes the need for a high level of suspicion when it comes to neonatal stroke, primarily in the presence of risk factors. The prevalence of neurological sequelae in our series supports the need of long-term follow-up and early intervention strategies.
\end{abstract}

Keywords: Stroke/complications; Infant; Infant, newborn; Risk factors; Seizures

\section{RESUMO}

Objetivo: Estudar incidência, apresentação clínica, fatores de risco, resultado de exames de imagem e desfecho clínico do acidente vascular cerebral perinatal. Métodos: Análise retrospectiva dos prontuários de recém-nascidos a termo internados com o diagnóstico de acidente vascular cerebral perinatal no Serviço de Neonatologia, de uma maternidade nível III, em Lisboa, de janeiro de 2007 a dezembro de 2011. Resultados: Houve 11 casos de acidente vascular cerebral: nove isquêmicos arteriais e duas tromboses dos seios venosos. As incidências foram estimadas: para acidente vascular cerebral isquêmico arterial de 1,6/5.000 nascimentos; para trombose dos seios venosos de 7,2/100.000 nascimentos. Houve dois casos de recorrência. Oito doentes foram sintomáticos e três assintomáticos, com diagnóstico incidental. As convulsões foram o sintoma mais frequente (8/11): clônicas generalizadas (3/8) e clônicas focais (5/8). 0 território vascular esquerdo foi o mais afetado (9/11), particularmente a artéria cerebral média esquerda (8/11). A ecografia transfontanelar foi positiva na maioria dos doentes (10/11), sendo o diagnóstico confirmado por ressonância magnética cerebral em todos. Dos cinco doentes que realizam eletroencefalograma, três apresentaram alterações (alterações focais $n=2$ e padrão de surto-supressão $n=1$ ). Oito doentes apresentaram fatores de risco para acidente vascular cerebral neonatal, incluindo causas obstétricas e neonatais. Dez doentes foram acompanhados em ambulatório, dos quais quatro apresentaram défice motores e um apresentou epilepsia. Conclusão: Apesar de uma amostra limitada e heterogênea, este estudo reforça a necessidade de um elevado nível de suspeita para acidente vascular cerebral perinatal, particularmente na presença de fatores de risco. A prevalência de sequelas neurológicas em nossa série reforça a necessidade de seguimento a longo prazo e de estratégias de intervenção precoces.

Descritores: Acidente vascular cerebral/complicações; Lactente; Recémnascido; Fatores de risco; Convulsões

\footnotetext{
${ }^{1}$ Maternidade Dr. Alfredo da Costa, Lisboa, Portugal.

Corresponding author: Sónia Pimentel - Serviço de Pediatria, Maternidade Dr. Alfredo da Costa - Rua Viriato - Zip code: 1069-089 - Lisboa, Portugal - Phone: +351 213184133 - E-mail: soniapimentel@yahoo.com Received on: Feb 3, 2014 - Accepted on: Jan 7, 2015

Conflict of interest: none.

DOI: 10.1590/\$1679-45082015A03056
} 


\section{INTRODUCTION}

Perinatal ischemic stroke is a cerebrovascular event around the time of birth with pathological or imaging evidence of focal vascular infarction. ${ }^{(1)}$ It can be defined as a heterogeneous group of conditions, in which there is focal disruption of cerebral blood flow secondary to arterial or cerebral venous thrombosis or embolization, between 20 weeks of fetal life through the $28^{\text {th }}$ postnatal day, confirmed by neuroimaging or neuropathological studies. $^{(2)}$

Two common subtypes of ischemic stroke diagnosed in the perinatal period are arterial ischemic stroke (AIS) and cerebral sinovenous thrombosis (CSVT). ${ }^{(3)}$

The reported incidence of neonatal acute ischemic stroke is approximately 1 per 4,000 to 5,000 full-term newborns. ${ }^{(4)}$ The incidence of sinus venous thrombosis ranges from 1 to 12 per 100,000 newborns, ${ }^{(5,6)}$ although some series have reported an incidence as high as almost 41 per 100,000 newborns. ${ }^{(7,8)}$

Perinatal ischemic stroke is thought to be an underdiagnosed condition as not all prenatal infarctions are symptomatic during the neonatal period. They may go on unrecognized if not significant enough to warrant brain imaging. ${ }^{(9)}$

Advanced neuroimaging techniques and their broadened availability have improved the diagnosis of stroke with an important impact on its prevalence. ${ }^{(10)}$ Today, there is a greater awareness of perinatal stroke as part of the differential diagnoses in newborns and infants with neurological symptoms.

Newborns are particularly susceptible to stroke due to the perinatal activation of coagulation mechanisms..$^{(1,11)}$ Several risk factors have been associated with perinatal stroke including: maternal disorders (infertility, preeclampsia, chorioamnionitis, placental vasculopathy, and cocaine abuse), fetal conditions (growth restriction, intrauterine asphyxia, heart diseases, infections, congenital vascular anomalies, dehydration, and traumatic delivery), and thrombophilia. ${ }^{(12,13)}$ Inherited and acquired thrombophilia have been gaining considerable attention as risk factors for perinatal stroke and their screening should be considered in patients with perinatal stroke. ${ }^{(12)}$ Prothrombotic disorders include elevated lipoprotein (a), factor V Leiden mutation, hyperhomocysteinemia, and protein $\mathrm{C}$ deficiency. ${ }^{(4)} \mathrm{It}$ is believed that multiple risk factors could manifest as cumulative morbidity (especially blood disorders with asphyxia stress). It should be noted that often the etiology goes unrecognized.

There is a male predominance as neonatal AIS and CSVT are more frequently diagnosed in boys (ratio 1.5 boys to 1 girl)..(14,15)
Perinatal stroke is thought to be a common cause of long-term neurologic disability and the leading cause of hemiplegic cerebral palsy. ${ }^{(16)}$ The common sequelae include motor deficits (rates range from $30 \%$ to $60 \%),{ }^{(17-20)}$ epilepsy (estimated rates range from zero to $50 \%),{ }^{(21)}$ cognitive impairment (less frequent than motor disabilities or seizure disorder), ${ }^{(17,22)}$ and behavioral disorders. A study reported cognitive impairment in $41 \%$ of children after neonatal stroke. ${ }^{(23)}$ Perinatal stroke has a low mortality. ${ }^{(24)}$

In this study the authors intended to share their unit's experience on perinatal stroke, as there are few epidemiological studies on this condition, and as far as we know, there are no data published on this topic, in Portuguese. ${ }^{(25)}$

\section{OBJECTIVE}

To evaluate the incidence, presentation, risk factors, imaging diagnosis, and clinical outcome of perinatal stroke in full-term newborns.

\section{METHODS}

We retrospectively reviewed all diagnosed cases of neonatal stroke in full-term newborns admitted to the neonatal unit of a maternity hospital (tertiary care), in Lisbon, from January $1^{\text {st }}, 2007$, to December 31 ${ }^{\text {st }}, 2011$. Confidentiality and data anonymity were preserved and there were no ethical issues concerned.

Since most studies regarding neonatal stroke include only full-term newborns, for the purpose of this study only these neonates were considered. ${ }^{(12)}$ Therefore, the inclusion criteria were: inborn full-term newborns ( $\geq 37$ weeks gestation at birth as assessed by fetal ultrasound at 12 to 13 weeks of gestation), with a hospital discharge diagnosis of perinatal stroke established by imaging diagnosis of a stroke area (AIS or CSVT) on a brain ultrasound or magnetic resonance imaging.

We excluded outborns, newborns with hypoxicischemic encephalopathy with criteria for therapeutic hypothermia (Apgar score $<5$ at 10 minutes, and/or prolonged resuscitation, and/or acidosis $-\mathrm{pH}<7.0$, and/or base deficit $>16 \mathrm{mmol} / \mathrm{L}$, plus moderate or severe clinical encephalopathy, up until 6 hours of age), and newborns with posterior diagnosis of inborn errors of metabolism.

The data collection included demographics (gender, birth weight, and gestational age), perinatal features (pregnancy disorders, delivery, Apgar score at 1 and 5 minutes, and resuscitation), family history of thrombophilia and other potential risk factors (cardiac 
and acute diseases), clinical presentation (age, and symptoms), diagnostic procedures (laboratory, imaging, and electrophysiological studies), treatments, and length of hospital stay. Outcomes were assessed by outpatient follow-up on multidisciplinary consultations that included regular evaluations by developmentalpediatrics, neuropediatrics, physical medicine and rehabilitation, and ophthalmology. Development evaluation was performed using the Bayley Scales of Infant and Toddler Development.

Prothrombotic study included screening for coagulation disorders (activated partial thromboplastin and prothrombin time), protein $\mathrm{C}$ and protein $\mathrm{S}$ deficiency, anticardiolipin antibodies, factor V Leiden, and methylenetetrahydrofolate reductase (MTHFR) mutations.

\section{RESULTS}

\section{Incidence}

A total of 504,814 live births were registered in Portugal during the 5-year study period (from 2007 through 2011). Of those, 27,612 occurred in our center (5.6\%).

Perinatal stroke was confirmed in 11 newborns (5 boys, 6 girls). There were nine patients with AIS and two patients with CSVT. The calculated incidence was, respectively, 1.6/5,000 and 7.2/100,000 live births.

\section{Clinical presentation}

Eight of the 11 patients presented with symptoms of the ischemic insult while the remaining three (cases 8, 9, and 11) had no clinical manifestation of the acute event and their diagnosis was retrospectively done. These patients had clinical risk factors that led to ultrasound assessment: peripheral arterial thrombosis (case 8), severe hypernatremic dehydration (case 9), low Apgar score, and need for resuscitation maneuvers (birth asphyxia with no criteria for therapeutic hypothermia case 11).

Most frequently registered symptoms were seizures, in all symptomatic patients (focal clonic $-5 / 8$, and generalized clonic $-3 / 8$ ), and apnea/low pulse oximetry levels (4/8). Infrequent presenting symptoms were bradycardia (1/8) and changes of muscular tone (1/8).

Most newborns were symptomatic within the first 48 hours of life (7/8), three cases before 24 hours of life and four cases between 24 to 48 hours of life. Two patients presented with symptoms before 1 week of life and two after this period.

\section{Risk factors}

Most cases (8/11) had gestational, obstetrical, and neonatal risk factors, including primiparity $(8 / 11)$, maternal age $\geq 35$ years old (3/11), gestational diabetes $(1 / 11)$, chorioamnionitis (2/11), meconium-stained amniotic fluid $(2 / 11)$, instrumental delivery $(7 / 11)$, need for resuscitation maneuvers $(2 / 11)$, dehydration $(1 / 11)$, and umbilical catheter $(2 / 11)$ (Chart 1$)$.

Prothrombotic screening detected abnormalities in five patients: protein-C deficiency in one and MTHFR mutation in four (two homozygotes, two heterozygotes). In nine children, more than one risk factor for neonatal stroke was detected.

Chart 1. Patients' demographic data and risk factors

\begin{tabular}{|c|c|c|c|c|c|c|c|c|c|}
\hline & & & & & & Risk & & & \\
\hline & Sex & GA (weeks) & MA & Primiparity & $\begin{array}{c}\text { Placenta/ } \\
\text { amniotic fluid }\end{array}$ & Delivery & RM & $\begin{array}{l}\text { Apgar Score } \\
1^{\text {st }} \mathbf{5}^{\text {th }} \text { minutes }\end{array}$ & Other \\
\hline 1 & $F$ & 38 & 38 & - & - & $\begin{array}{c}\text { Caesarean } \\
\text { section }\end{array}$ & - & $10 / 10$ & MTHFR mutation homozygous \\
\hline 2 & M & 38 & 33 & $(+)$ & $\begin{array}{c}\text { Chorioamnionitis } \\
\text { Meconium }\end{array}$ & Forceps & - & $8 / 10$ & MTHFR mutation homozygous \\
\hline 3 & $\mathrm{~F}$ & 40 & 38 & - & - & Eutocic & - & $9 / 10$ & - \\
\hline 4 & M & 39 & 31 & $(+)$ & - & Vacuum & $(+)$ & $6 / 9$ & MTHFR mutation heterozygous \\
\hline 5 & $\mathrm{~F}$ & 40 & 22 & $(+)$ & - & Vacuum & - & $8 / 10$ & Protein $\mathrm{C}$ deficiency \\
\hline 6 & M & 38 & 32 & - & - & $\begin{array}{l}\text { Caesarean } \\
\text { section }\end{array}$ & - & $9 / 10$ & Gestational diabetes \\
\hline 7 & F & 38 & 30 & $(+)$ & - & $\begin{array}{l}\text { Caesarean } \\
\text { section }\end{array}$ & - & $8 / 10$ & MTHFR mutation heterozygous \\
\hline 8 & $\mathrm{~F}$ & 38 & 30 & $(+)$ & $\begin{array}{c}\text { Chorioamnionitis } \\
\text { Meconium }\end{array}$ & Eutocic & - & $8 / 10$ & Peripheral arterial thrombosis / UC \\
\hline 9 & $\mathrm{~F}$ & 39 & 28 & $(+)$ & - & Eutocic & - & $9 / 10$ & Dehydration \\
\hline 10 & M & 41 & 19 & $(+)$ & - & Eutocic & - & $8 / 8$ & - \\
\hline 11 & $M$ & 37 & 37 & $(+)$ & - & Forceps & $(+)$ & $2 / 4$ & UC \\
\hline
\end{tabular}

GA: gestational age; MA: maternal age; RM: resuscitation maneuvers; F: female; MTHFR: methylenetetrahydrofolate reductase; M: male; UC: umbilical catheter 


\section{Neuroimaging techniques}

All patients with seizures were investigated by brain ultrasonography (8/11). The imaging diagnosis by ultrasonography of a stroke area was also incidentally made in three patients who were assessed due to risk neurological conditions (peripheral arterial thrombosis, severe hypernatremic dehydration, and birth asphyxia without criteria for therapeutic hypothermia).

Brain ultrasonography was positive in most patients (10/11, sensitivity 91\%). One newborn (case 1) that had a normal ultrasonography went to brain magnetic resonance imaging because of a high clinical suspicion of stroke. The diagnosis of stroke was confirmed by brain magnetic resonance imaging in all patients.
Vascular territory of the middle cerebral artery was involved in all cases of AIS: left- (7/9) and right-sided (2/9) arteries. Regarding CSVT, there was involvement of the lateral left $(2 / 2)$ and superior longitudinal sinuses $(1 / 2)$.

There were two cases of recurrence: one CSVT (case 11: left lateral sinus thrombosis recurred in the right sinus) and one AIS (case 8: recurred with sinus venous thrombosis and had involvement of the left lateral and sigmoid sinuses) (Chart 2).

Standard electroencephalography was carried out in five patients, and was abnormal in three. The results showed focal abnormalities (2/3) and a burst-suppression pattern $(1 / 3)$.

Chart 2. Patients' clinical presentations, diagnostic tests, and follow-up

\begin{tabular}{|c|c|c|c|c|c|c|c|c|c|}
\hline & \multicolumn{3}{|c|}{ Diagnosis } & \multirow[b]{2}{*}{ Brain US } & \multirow[b]{2}{*}{ MRI } & \multirow[b]{2}{*}{ EEG } & \multirow[b]{2}{*}{ Vascular territory } & \multicolumn{2}{|c|}{ Follow-up } \\
\hline & Days & Seizure & $\begin{array}{c}\text { Systemic } \\
\text { symptoms }\end{array}$ & & & & & $\begin{array}{c}\text { Age } \\
\text { (months) }\end{array}$ & $\begin{array}{c}\text { Sequelae/age at } \\
\text { onset }\end{array}$ \\
\hline 1 & 2 & Generalized clonic & $\begin{array}{l}\text { Low pulse } \\
\text { oximetry levels }\end{array}$ & Normal & AIS & Normal & Left MCA & 6 & Hemiparesis \\
\hline \multirow[t]{2}{*}{2} & 2 & Focal clonic & $\begin{array}{c}\text { Low pulse } \\
\text { oximetry levels }\end{array}$ & $\begin{array}{l}\text { Left temporoparietal } \\
\text { hyperechogenicity }\end{array}$ & AIS & - & Left MCA & 48 & $\begin{array}{l}\text { Monoparesis } \\
\text { (upper limb) }\end{array}$ \\
\hline & & & Apnea & & & & & & $(3 \mathrm{M})$ \\
\hline \multirow[t]{2}{*}{3} & 1 & Focal clonic & $\begin{array}{l}\text { Low pulse } \\
\text { oximetry levels }\end{array}$ & $\begin{array}{l}\text { Left frontoparietal } \\
\text { hyperechogenicity }\end{array}$ & AIS & - & Left MCA & 36 & - \\
\hline & & & $\begin{array}{c}\text { Apnea } \\
\text { Bradycardia }\end{array}$ & & & & & & \\
\hline 4 & 1 & Generalized clonic & - & $\begin{array}{l}\text { Left frontoparietal } \\
\text { hyperechogenicity }\end{array}$ & AIS & - & Left MCA & 48 & - \\
\hline \multirow[t]{2}{*}{5} & 9 & Generalized clonic & - & $\begin{array}{l}\text { Left frontoparietal } \\
\text { hyperechogenicity }\end{array}$ & AIS & $\begin{array}{l}\text { Burst-suppression } \\
\text { pattern }\end{array}$ & Left MCA & 27 & $\begin{array}{c}\text { Hemiparesis (0M) } \\
\text { Epilepsy (6M) }\end{array}$ \\
\hline & & & & & & & & & No language \\
\hline 6 & 1 & Focal clonic & $\begin{array}{c}\text { Low pulse } \\
\text { oximetry levels }\end{array}$ & $\begin{array}{l}\text { Left temporal } \\
\text { hyperechogenicity }\end{array}$ & AIS & $\begin{array}{l}\text { Left temporal } \\
\text { paroxysmal activity }\end{array}$ & Left MCA & - & - \\
\hline 7 & 2 & Focal clonic & - & $\begin{array}{l}\text { Left frontoparietal } \\
\text { hyperechogenicity }\end{array}$ & AIS & Normal & Left MCA & 12 & - \\
\hline 8 & 3 & - & - & $\begin{array}{l}\text { Right temporoparietal } \\
\text { hyperechogenicity }\end{array}$ & AIS & $\begin{array}{l}\text { Epileptic focus on the } \\
\text { right hemisphere }\end{array}$ & $\begin{array}{l}\text { Right ACM recurred lateral } \\
\text { left and sigmoid sinuses }\end{array}$ & 15 & $\begin{array}{c}\text { Hemiparesis (0M) } \\
\text { Epilepsy (5M) }\end{array}$ \\
\hline 9 & 5 & - & - & $\begin{array}{c}\text { Right temporal } \\
\text { hyperechogenicity }\end{array}$ & AIS & - & Right MCA & 18 & - \\
\hline 10 & 2 & Focal clonic & Hypotonia & $\begin{array}{c}\text { Subcortical } \\
\text { hyperechogenicity }\end{array}$ & CSVT & - & Superior and left lateral sinus & 24 & - \\
\hline 11 & 10 & - & - & $\begin{array}{c}\text { Subcortical } \\
\text { hyperechogenicity }\end{array}$ & CSVT & - & $\begin{array}{l}\text { Left lateral sinus recurred } \\
\text { right lateral sinus }\end{array}$ & 18 & - \\
\hline
\end{tabular}

US: ultrasonography; MRI: magnetic resonance imaging; EEG: electroencephalogram; AIS: arterial ischemic stroke; MCA: middle cerebral artery; CSVT: cerebral sinus venous thrombosis.

\section{Treatment}

Most patients (8/11) were treated with anticonvulsants. Most seizures were successfully treated with phenobarbital, and no anticonvulsant associations were needed.

Antithrombotic medication was uncommon (2/11): the patient with recurrent CSVT (case 11) was treated with low-molecular-weight heparin, and the patient with AIS, CSVT, and arterial peripheral thrombosis (case 8) with unfractionated heparin. There were no complications related to the antithrombotic therapy. Antiplatelets were not given to patients.

\section{Outcome}

The mean duration of hospital stay was 17 days (range 11 to 26 days). There were no deaths during the study period. 
Ten patients were followed up as outpatients. The mean follow-up time was 2 years, ranging from 6 months to 4 years. Neurodevelopmental outcome was abnormal in four patients. One patient (case 5) had an underlying condition (hemimegalencephaly) that could be cause of stroke. The remaining six patients became seizure-free and had no motor, cognitive, or behavioral disability during follow-up.

\section{DISCUSSION}

This study described the clinical presentation and follow-up of a small group of full-term newborns with perinatal ischemic stroke born at our center.

There was a slightly higher incidence of AIS in our series than previously reported.

The clinical presentation of perinatal stroke varies from nonspecific symptoms, to obvious neurological symptoms, which can be misleading. In our series, seizures were the most common clinical manifestation in $72.7 \%$ of the patients, mainly focal clonic, which is consistent with published data. ${ }^{(26)}$ As described in the literature, seizures are common with ischemia in children, especially in newborns, and they are frequently the most common clinical finding triggering assessment in newborns. ${ }^{(13)}$ In a few patients $(27.2 \%)$, the event was clinically silent.

Up to two-thirds of our patients $(63.6 \%)$ were symptomatic in the first 48 hours of life, which should be the period of highest awareness of clinical stroke manifestations.

When other signs and symptoms were present, they were frequently nonspecific and subtle and included abnormalities of tone, lethargy, apnoea, ${ }^{(15)}$ feeding difficulties, temperature or hemodynamic instability $(10,27)$ (Chart 2). For this reason, in order to promote early recognition and diagnosis, one should always look carefully for other clinical signs (frequently more subtle than neonatal seizures), mainly in the presence of risk factors. $^{(25)}$

Diagnostic imaging methods for the suspected cases of perinatal stroke include brain ultrasonography, computed tomography, and magnetic resonance imaging. Magnetic resonance imaging is the most accurate and reliable method to detect early stroke and has no radiation risk. ${ }^{(28)}$ It is therefore the imaging modality of choice for the diagnose of acute perinatal stroke. ${ }^{(29,30)}$

Neuroimaging assessment in our study relied on brain ultrasonography and magnetic resonance imaging. Brain ultrasonography is easier to perform and more accessible at our center, and was therefore the first neuroimaging exam performed in all patients with suspected stroke. Although in the literature brain ultrasonography is described as a low sensitivity indicator of perinatal stroke, in our series it had a sensitivity of $91 \% .^{(31,32)}$ The diagnosis was established in all patients by magnetic resonance imaging.

Standard electroencephalography should be carried out for suspicious clinical seizure activity, as it is commonly one of the first diagnostic tools available at the bedside in the neonatal intensive care unit for the assessment of cerebral function. ${ }^{(33,34)}$

In ourstudy, electroencephalogram(EEG) monitoring was not a common practice, and although this might be questionable, it is justified by the limited availability of EEG equipment in our unit. Standard EEG is reserved for severe, repeated, or prolonged seizures. Continuous EEG is of relevance in the differential diagnosis of stroke and hypoxic-ischemic encephalopathy; nevertheless it was not available in our unit during the study period.

The ischemic lesions were most often observed in the distribution of the middle cerebral artery (81.8\%), particularly on the left side $(63.6 \%)$. This finding is consistent with the literature. ${ }^{(35)}$ This predominance of lesions on the left side is thought to be due to differences in vulnerability and maturation or to the presence of vascular asymmetries. ${ }^{(36)}$ The left hemisphere may also be more vulnerable to embolic lesions due to hemodynamic differences from a patent ductus arteriosus or through the direct route involving the left common carotid artery. ${ }^{(23,36)}$

Perinatal stroke is thought to have a diverse underlying aetiology and several risk factors are frequently cited, although only a few case-control studies have systematically investigated them. ${ }^{(29)}$ We found at least one risk factor in all patients. There was a significant percentage of instrumental deliveries $(63.6 \%)$, which is a known main risk for neonatal stroke. ${ }^{(37)}$ A significant number of patients $(45.5 \%)$ had prothrombotic abnormalities sustaining the concept that they may have a considerable influence in the etiology of perinatal stroke. ${ }^{(12,38)}$ It is noteworthy that prothrombotic screening was carried out in all patients, but different prothrombotic abnormalities were assessed in each patient. Therefore, the retrospective nature of this study may have reduced its ability to identify neonatal risk factors and the accurate prevalence of thrombophilia alterations in our population.

The most frequently identified risk factors in our series included both gestational and delivery complications. These are often associated with fetal distress or hypoxia and have been stated as one of the possible causes of neonatal stroke, although large-scale prospective 
clinical studies are still warranted when it comes to establishing neonatal stroke etiology. ${ }^{(39)}$

Several patients $(63.6 \%)$ had more than one risk factor, which may support the hypothesis that this could be a multifactorial disorder with several potential and cumulative risk factors. ${ }^{(40)}$

Management and treatment of perinatal ischemic stroke remain to be established. The American College of Chest Physicians recommends anticoagulation therapy in neonates with a first AIS if there is evidence of an ongoing documented cardioembolic source and in the cases of CSVT in the absence of significant intracranial hemorrhage. ${ }^{(41)}$ For neonates with peripheral arterial thrombosis, anticoagulation is also recommended alongside with immediate catheter removal. ${ }^{(41)}$ Anticoagulation was infrequent in our series: one case of AIS (because the patient also had peripheral thrombosis) and one case of recurrence of CSVT. In these two patients, this therapy was safe and no complications were reported.

The frequent use of anticonvulsants was expected, since most $(72.7 \%)$ patients presented with seizures. There is a lack of guidelines concerning the optimal length of anticonvulsant treatment. In our series it was maintained at least until hospital discharge.

The majority of the patients $(60 \%)$ had no neurological sequelae. This may be misleading due to the short time of follow-up. If motor disabilities and epilepsy are usually apparent early in childhood, other abnormalities, related to cognitive functions and behavioral abnormalities may take longer to be noticeable.

\section{CONCLUSION}

The high incidence of perinatal arterial ischemic stroke and cerebral sinovenous thrombosis found in our series reinforces the fact that this remained a serious problem in the neonate.

Even though many risk factors, including gestational and delivery complications, were found in our patients, we believe that the retrospective nature of the current study and the small sample of patients may have reduced its ability to find predictive significance for these risk factors.

Brain ultrasonography is a noninvasive and easily accessible intervention for the evaluation of stroke that in our series proved to be a reliable diagnostic tool.

Although we found a favorable outcome in the majority of our patients, we believe that a much longer follow-up period will be required for a meaningful interpretation of their neurological outcome.
The results of the current study reflect the reality of our maternity, which is similar to many other maternities with newborns at low-to-median risk of stroke. Despite a modest sample size and a heterogeneous population, the shortage of studies makes every report of great value when it comes to understanding this condition, identifying possible risk factors, and improving its management.

\section{REFERENCES}

1. Nelson KB, Lynch JK. Stroke in newborn infants. Lancet Neurol. 2004;3(3):150-8 Review.

2. Raju TN, Nelson KB, Ferriero D, Lynch JK; NICHD-NINDS Perinatal Stroke Workshop Participants. Ischemic perinatal stroke: summary of a workshop sponsored by the National Institute of Child Health and Human Development and the National Institute of Neurological Disorders and Stroke. Pediatrics. 2007:120(3):609-16

3. Govaert P, Ramenghi L, Taal R, de Vries L, Deveber G. Diagnosis of perinata stroke I: definitions, differential diagnosis and registration. Acta Paediatr. 2009;98(10):1556-67.

4. Lynch JK. Epidemiology and classification of perinatal stroke. Semin Feta Neonatal Med. 2009:14(5):245-9.

5. Berfelo FJ, Kersbergen KJ, van Ommen CH, Govaert P, van Straaten HL, Poll-The BT, et al. Neonatal cerebral sinovenous thrombosis from symptom to outcome. Stroke. 2010;41(7):1382-8.

6. Rutherford MA, Ramenghi LA, Cowan FM. Neonatal stroke. Arch Dis Child Fetal Neonatal Ed. 2012;97(5):F377-84.

7. deVeber G, Andrew M, Adams C, Bjornson B, Booth F, Buckley DJ, Camfield CS, David M, Humphreys P, Langevin P, MacDonald EA, Gillett J, Meaney B, Shevell M, Sinclair DB, Yager J; Canadian Pediatric Ischemic Stroke Study Group. Cerebral sinovenous thrombosis in children. N Engl J Med. $2001 ; 345(6): 417-23$

8. Yang JY, Chan AK, Callen DJ, Paes BA. Neonatal cerebral sinovenous thrombosis: sifting the evidence for a diagnostic plan and treatment strategy. Pediatrics. 2010;126(3):e693-700. Review.

9. Chabrier S, Husson B, Dinomais M, Landrieu P, Nguyen The Tich S. New insights (and new interrogations) in perinatal arterial ischemic stroke. Thromb Res. 2011;127(1):13-22. Review.

10. Govaert P, Smith L, Dudink J. Diagnostic management of neonatal stroke. Semin Fetal Neonatal Med. 2009;14(5):323-8

11. Saxonhouse MA, Burchfield DJ. The evaluation and management of postnata thromboses. J Perinatol. 2009;29(7):467-78.

12. Chalmers EA. Perinatal stroke-risk factors and management. Br J Haematol. 2005;130(3):333-43. Review.

13. Goodman S, Pavlakis S. Pediatric and newborn stroke. Curr Treat Options Neurol 2008;10(6):431-9.

14. Golomb MR, Dick PT, MacGregor DL, Curtis R, Sofronas M, deVeber GA Neonatal arterial ischemic stroke and cerebral sinovenous thrombosis are more commonly diagnosed in boys. J Child Neurol. 2004;19(7):493-7.

15. Miller V. Neonatal cerebral infarction. Semin Pediatr Neurol. 2000;7(4):278-88 Review.

16. Nelson KB. Perinatal ischemic stroke. Stroke. 2007;38(2 Suppl):742-5. Review

17. deVeber GA, MacGregor D, Curtis R, Mayank S. Neurologic outcome in survivors of childhood arterial ischemic stroke and sinovenous thrombosis. J Child Neurol. 2000;15(5):316-24.

18. Ganesan V, Hogan A, Shack N, Gordon A, Isaacs E, Kirkham FJ. Outcome after ischaemic stroke in childhood. Dev Med Child Neurol. 2000;42(7):455-61.

19. Lee J, Croen LA, Lindan C, Nash KB, Yoshida CK, Ferriero DM, et al. Predictors of outcome in perinatal arterial stroke: a population-based study. Ann Neurol. 2005;58(2):303-8. 
20. Mercuri E, Barnett A, Rutherford M, Guzzetta A, Haataja L, Cioni G, et al. Neonatal cerebral infarction and neuromotor outcome at school age. Pediatrics. 2004;113(1 Pt 1):95-100.

21. Golomb MR, Garg BP, Carvalho KS, Johnson CS, Williams LS. Perinatal stroke and the risk of developing childhood epilepsy. J Pediatr. 2007;151(4):409-13, 413 e1-2.

22. Hartel C, Schilling S, Sperner J, Thyen U. The clinical outcomes of neonatal and childhood stroke: review of the literature and implications for future research. Eur J Neurol. 2004;11(7):431-8. Review.

23. Sreenan $C$, Bhargava R, Robertson CM. Cerebral infarction in the term newborn: clinical presentation and long-term outcome. J Pediatr. 2000;137(3):351-5.

24. Aden U. Neonatal stroke is not a harmless condition [editorial]. Stroke. 2009; 40(6):1948-9.

25. Laugesaar R, Kolk A, Tomberg T, Metsvaht $T$, Lintrop $M$, Varendi $H$, et al. Acutely and retrospectively diagnosed perinatal stroke: a population-based study. Stroke. 2007;38(8):2234-40.

26. Armstrong-Wells J, Ferriero DM. Diagnosis and acute management of perinatal arterial ischemic stroke. Neurol Clin Pract. 2014;4(5):378-85.

27. Roodhooft AM, Parizel PM, Van Acker KJ, Deprettere AJ, Van Reempts PJ. Idiopathic cerebral arterial infarction with paucity of symptoms in the fullterm neonate. Pediatrics. 1987;80(3):381-5.

28. Lequin MH, Dudink J, Tong KA, Obenaus A. Magnetic resonance imaging in neonatal stroke. Semin Fetal Neonatal Med. 2009;14(5):299-310.

29. Sehgal A. Perinatal stroke: a case-based review. Eur J Pediatr. 2012;171(2):225-34. Review.

30. Venkataraman A, Kingsley PB, Kalina P, Pavlakis SG, Buckwald S, Spinazzola $\mathrm{R}$, et al. Newborn brain infarction: clinical aspects and magnetic resonance imaging. CNS Spectr. 2004;9(6):436-44.
31. Estan J, Hope P. Unilateral neonatal cerebral infarction in full term infants. Arch Dis Child Fetal Neonatal Ed. 1997;76(2):F88-93.

32. Golomb MR, Dick PT, MacGregor DL, Armstrong DC, DeVeber GA. Cranial ultrasonography has a low sensitivity for detecting arterial ischemic stroke in term neonates. J Child Neurol. 2003;18(2):98-103.

33. Clancy RR. Summary proceedings from the neurology group on neonatal seizures. Pediatrics. 2006;117(3 Pt 2):S23-7.

34. Low E, Mathieson SR, Stevenson NJ, Livingstone V, Ryan CA, Bogue CO, et al. Early postnatal EEG features of perinatal arterial ischaemic stroke with seizures. PLoS One. 2014;9(7):e100973.

35. Perlman JM, Rollins NK, Evans D. Neonatal stroke: clinical characteristics and cerebral blood flow velocity measurements. Pediatr Neurol. 1994;11(4):281-4.

36. Salih MA, Abdel-Gader AG, Al-Jarallah AA, Kentab AY, Alorainy IA, Hassan $\mathrm{HH}$, et al. Perinatal stroke in Saudi children. Clinical features and risk factors. Saudi Med J. 2006;27 Suppl 1:S35-40.

37. Koelfen W, Freund M, Varnholt V. Neonatal stroke involving the middle cerebral artery in term infants: clinical presentation, EEG and imaging studies, and outcome. Dev Med Child Neurol. 1995;37(3):204-12.

38. Lynch JK, Hirtz DG, DeVeber G, Nelson KB. Report of the National Institute of Neurological Disorders and Stroke workshop on perinatal and childhood stroke. Pediatrics. 2002;109(1):116-23.

39. Luo L, Chen D, Qu Y, Wu J, Li X, Mu D. Association between hypoxia and perinatal arterial ischemic stroke: a meta-analysis. PLoS One. 2014;9(2):e90106.

40. Fernández-López D, Natarajan N, Ashwal S, Vexler ZS. Mechanisms of perinatal arterial ischemic stroke. J Cereb Blood Flow Metab. 2014;34(6):921-32. Review.

41. Monagle P, Chan AK, Goldenberg NA, et al. Antithrombotic therapy in neonates and children: Antithrombotic Therapy and Prevention of Thrombosis, 9th ed: American College of Chest Physicians Evidence-Based Clinical Practice Guidelines. Chest. 2012;141(2 Suppl):e737S-801S. 